\title{
The Use of Pa Kua Mirror According to Feng Shui by the Chinese Ethnic in Kotapinang
}

\author{
Tri Rahma Dana \\ \{rahmatridana@yahoo.co.id\} \\ Postgraduate Social Anthropology, Universitas Negeri Medan, Indonesia
}

\begin{abstract}
This study aims to determine the use of $\mathrm{Pa}$ Kua (Ba Gua) mirrors by ethnic Chinese in Kotapinang District, Labuhanbatu Selatan. This research was carried out through James Spradley's ethnographic qualitative research. The data collection techniques were conducted through interviews, observation and documentation study. The results showed that the mirror with an octagonal shape was divided into two forms, namely Convex (eliminating negative energy) and Concave (capturing positive energy) made of aluminum and silver, believed by many ethnic Chinese to capture good things and drive out things bad things that are usually placed outside the house above the entrance of the house. This mirror is one of the Feng Shui products which is believed to provide protection and things that are considered good for those who believe in it. The use of $\mathrm{Pa} \mathrm{Kua}$ mirrors for ethnic Chinese is equated with the indigenous population who believe in shamans for things that are considered good. To be able to use the Pa Kua mirror properly, the mirror must be in Hoi Kong first then it can be used. Trusting Feng Shui and mirrors is not a necessity that must be done by all ethnic Chinese in Kotapinang, because there are some ethnic Chinese who choose not to trust Feng Shui or the Pa Kua mirrors.
\end{abstract}

Keywords: Pa Kua mirrors, Chinese Ethnic, Feng Shui, Hoi Kong

\section{Introduction}

The mirror is often used as a tool to design a space to look wider if space has a narrow scope, but not infrequently also many mirrors are used only as a decoration to beautify the desired space. If we want to talk about mirrors, why should ethnic Chinese become the subject? All ethnic groups use mirrors in their daily lives. What is interesting thing about this research is that what is discussed is not an ordinary mirror but a mirror of $\mathrm{Pa} \mathrm{Kua}$, a Feng Shui mirror that is usually used by ethnic Chinese who believe in Feng Shui. Why is this mirror so important to discuss? In using this Pa Kua mirror, some rules must be observed when using it, such as what kind of $\mathrm{Pa} \mathrm{Kua}$ mirror should be displayed above the entrance of the house, and whether this

Pa Kua mirror before being placed must be blessed first by Feng Shui experts or not. And what kind of strength is there in $\mathrm{Pa} \mathrm{Kua's} \mathrm{mirror} \mathrm{so} \mathrm{that} \mathrm{it} \mathrm{can} \mathrm{block} \mathrm{negative} \mathrm{energy} \mathrm{and}$ absorb positive energy for its owner [7]. In general, mirrors have three types, namely flat, concave and convex mirrors. Pa Kua's mirror is only divided into two types, concave and convex. $\mathrm{Pa}$ Kua convex has the same properties as a regular convex mirror that reflects the image to be smaller than the original object and for $\mathrm{Pa} \mathrm{Kua}$ 'sconvex mirror because it makes the reflection smaller and then fends off the negative energy around the house that forces it to 
enter and harm occupants of the house. Whereas $\mathrm{Pa} \mathrm{Kua's} \mathrm{concave} \mathrm{mirror} \mathrm{also} \mathrm{has} \mathrm{the} \mathrm{same}$ basic principle of nature as an ordinary concave mirror, which makes the reflection of objects look large. Because it enlarges the image of objects usually this mirror is used to absorb the positive energy that is around the house.

Therefore, ideally, the $\mathrm{Pa}$ Kua mirror should be placed in twos, concave and convex. $\mathrm{Pa}$ $K u a$ 's concave mirror usually has the symbol of a tiger and is passive, ideally placed on the right that serves as a windfall. While $\mathrm{Pa} \mathrm{Kua}$ 's convex mirror which usually has a dragon symbol and is active which is ideally placed on the left and serves as a reinforcement. But not infrequently some ethnic Chinese make mistakes in placing this $\mathrm{Pa}$ Kua mirror. This usually happens because of their ignorance of how to place this mirror, and only rely on trust in this mirror. As a result, $\mathrm{Pa} \mathrm{Kua's} \mathrm{mirror} \mathrm{did} \mathrm{not} \mathrm{function} \mathrm{as} \mathrm{it} \mathrm{should.} \mathrm{Like} \mathrm{the} \mathrm{response} \mathrm{of} \mathrm{the}$ Chinese community in Hong Kong at the time of the death of the legendary actor Bruce Lee at the time.

Many people there who consider Bruce Lee's death due to mirror Bagua in the home of Bruce Lee falling during high wind so bad energy then hit the psyche of Bruce Lee. The community stated that based on information by Feng Shui experts who were brought to Bruce Lee's house to see the condition of the house and what happened was as reported. So the greater the sense of trust of the Chinese community in Hong Kong, which eventually made it a hereditary tradition and carried out until finally the ethnic Chinese in Kotapinang also believed in it [1].

Kotapinang is a sub-district and central government of South Labuhanbatu Regency, North Sumatra, Indonesia. The distance of this city is $345 \mathrm{~km}$ from the city of Medan, the capital of the province of North Sumatra. Previously, the capital of this sub-district, Kotapinang which is also the capital of South Labuhanbatu Regency was once the capital of the Sultanate of Pinang City. The Chinese ethnic in Kotapinang is a minority ethnic group there, but although as a minority ethnic, the Chinese ethnic can show its existence both in terms of its socialization life with other ethnic groups and in terms of its economy which is known as a large capital owner. But if they see whether they believe in Feng Shui as their tradition, not all ethnic Chinese believe in it.

\section{Result and discussion}

What makes this Pa Kua mirror so special is that it is used by the ethnic Chinese in Kotapinang that this octagonal mirror has a meaning as a carrier of goodness for those who believe in it and use it in their lives. Because if we observe it more deeply, in the mirror of $\mathrm{Pa}$ Kua there is a trigram line as a director and five elements of life that are believed by the ethnic Chinese themselves to prosper their lives, such as the elements of fire, water, earth, metal, and wood. Each of these elements brings the good we need by using this $\mathrm{Pa}$ Kua mirror, such as wealth, fame, family, a relationship, creativity and children, career, freedom, and helping others [5]. Figure 1 below is the mirror of $\mathrm{Pa} \mathrm{Kua.}$ 

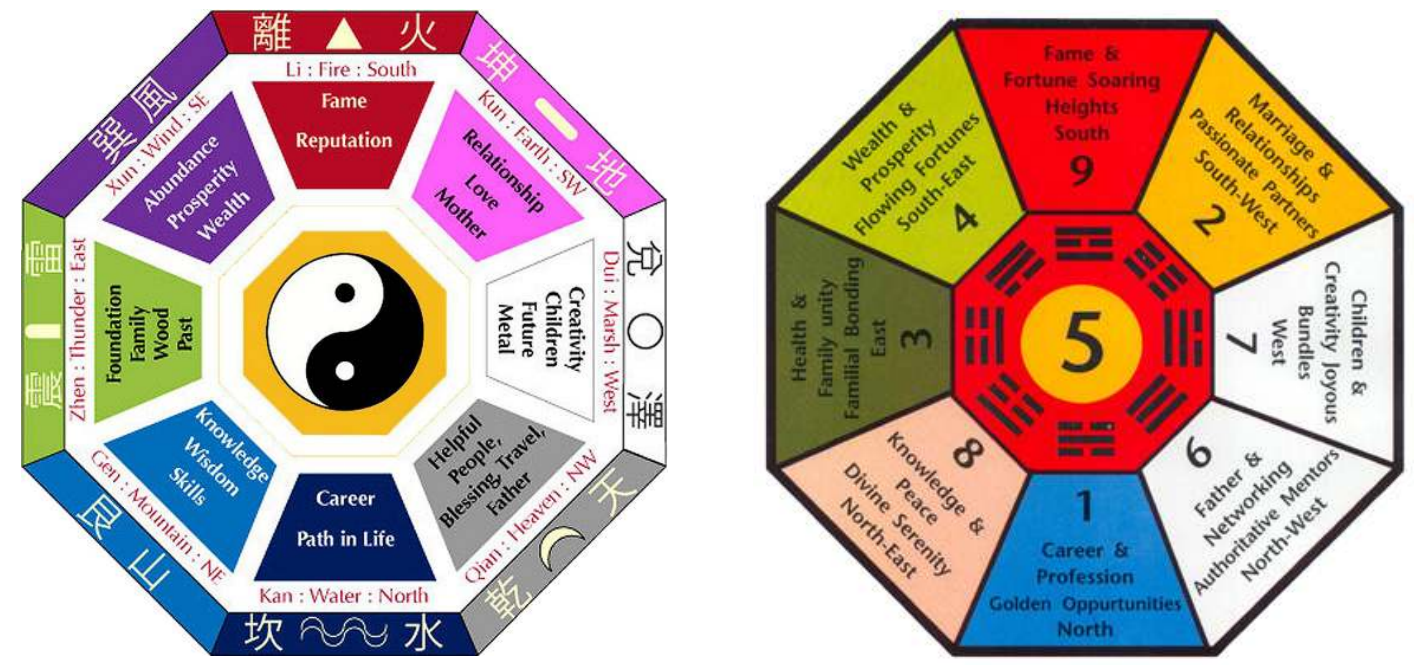

Fig.1. Pa Kua mirror Source: google.com

Mirror $\mathrm{Pa} \mathrm{Kua}$ will be perceived as its usefulness in warding off negative energy (Yin) and absorb the positive energy (Yang) which is nearby if the mirror Pa Kuagets the Hoi Kong first. Hoi Kong means "to open its eyes" according to Feng Shui experts. If it doesn't get Hoi Kong, then $\mathrm{Pa} K u a^{\prime}$ 's mirror will not have any effect or it is the same as an ordinary mirror. Hoi Kong means putting Chi or good energy into $\mathrm{Pa} \mathrm{Kua's} \mathrm{mirror.} \mathrm{After} \mathrm{the} \mathrm{Hoi} \mathrm{Kong}$ process, the Pa Kua mirror can be used to ward off evil energy and absorb good energy.

The mirror of $\mathrm{Pa} \mathrm{Kua}$ has changed shape since a long time ago until now. But the changes that occurred did not make $\mathrm{Pa} \mathrm{Kua's} \mathrm{mirror} \mathrm{lose} \mathrm{its} \mathrm{meaning} \mathrm{and} \mathrm{function} \mathrm{from} \mathrm{the} \mathrm{past} \mathrm{until}$ now has remained the same, namely counteracting negative energy (Yin) and absorbing positive energy (Yang). The shape of the traditional Pa Kua mirror is octagonal and there is a mirror in the middle of it. Meanwhile, $\mathrm{Pa} \mathrm{Kua}$ 's mirror is still octagonal, but in the middle, there is no longer using a mirror and is replaced by a dragon and tiger symbol.

Also from the material used has changed, such as the traditional Pa Kua mirror made of aluminum and silver, now this $\mathrm{Pa} K u a$ mirror is mostly made of wood and even plastic. But the function of the $\mathrm{Pa} \mathrm{Kua} \mathrm{mirror} \mathrm{does} \mathrm{not} \mathrm{change} \mathrm{if} \mathrm{the} \mathrm{way} \mathrm{to} \mathrm{use} \mathrm{it} \mathrm{is} \mathrm{done} \mathrm{correctly} \mathrm{and}$ according to the directions of Feng Shui experts. Because the most important thing for the Pa Kua mirror to function properly must be done by Hoi Kong or "to open its eyes" first. Putting trust in Feng Shui is not a necessity that must be possessed by the Chinese, especially the Chinese in Kotapinang. After conducting more in-depth observations, the writer found that there were several ethnic Chinese whose writers interviewed that they did not trust the $\mathrm{Pa} \mathrm{Kua}$ or Feng Shui mirrors, one of which said as follows.

"...I don't believe in Feng Shui or Pa Kua's mirror. Indeed, I see many of my friends who use mirrors, being stabbed at home, in their shops, but I can't believe it. Besides, in our holy book, there was no mention of Feng Shui to be trusted. For me, if people want to believe it, it's okay, but I still don't believe it ..." 
The Chinese mistrust was caused by the scriptures that they believed did not teach the existence of Feng Shui to be believed as a guide to their lives. But there are always pros and cons to a problem. Some ethnic Chinese in Kotapinang also believe in the existence of Feng Shui and the $\mathrm{Pa}$ Kua mirror. The writer asks why they trust both Feng Shui and $\mathrm{Pa} \mathrm{Kua's}$ mirror, one of the informants answered as follows:

"...Feng Shui is not a heresy, Feng Shui is necromancy of the earth which has a good purpose, helping humans to live in harmony with nature. Even though Feng Shui or Pa Kua's mirror is not written in the religious scriptures that I believe in, studying science with good intentions doesn't matter ..."

Deciding to believe it or not will depend on individual preference, it's like pros and cons in some certain issues are considered reasonable because the huge difference of people's point of view, thus the perspectives which are being used are different too.

\section{Conclusion}

Pa Kua mirror is one of the Feng Shui that existed from the beginning until now, although it has changed its shape its function remains unchanged if its use is as specified, i.e. hoikong first before use. This is where hoikong is done by a Feng Shui expert is the core of the conditions for using a $\mathrm{Pa} \mathrm{Kua's} \mathrm{mirror} \mathrm{so} \mathrm{that} \mathrm{the} \mathrm{mirror} \mathrm{can} \mathrm{function} \mathrm{properly.} \mathrm{The} \mathrm{ideal} \mathrm{use}$ of this $\mathrm{Pa} \mathrm{Kua} \mathrm{mirror}$ is to install a concave and convex mirror at the same time under their respective positions above the main entrance. But there are always pros and cons to a problem. Some ethnic Chinese in Kotapinang believe in the existence of Feng Shui and the Pa Kua mirror. And others don't believe in Feng Shui and also Pa Kua mirror.

\section{References}

[1] Bloomfield, Frena.Chinese Beliefs: Mendalami Pola-pola Berfikir Orang Cina. Surabaya: Liris. (2010)

[2] Gondomono. Membanting Tulang Menyembah Arwah: Kehidupan Kekotaan Masyarakat Cina. Jakarta: Pustaka Firdaus. (1996)

[3] Low, Albert.: Feng Shui Praktis Untuk Rumah Tangga. Jakarta: Megapoin. (2003)

[4] Morgan, Harry T. China Simbol dan Mistik. Yogyakarta: Alfamedia. (2007)

[5] Too, Lillian. Feng Shui. Jakarta: PT. Elex Media Komputindo. (1995)

[6] Rahardjo, Mauro. Mengubah Energi Rumah Meningkatkan Peruntungan. Jakarta: Gramedia. (2004)

[7] Kustedja, Sugiri. Sudikno, Antariksa \& Salura, Purnama.: Feng-shui: Elemen Budaya Tionghoa Tradisional. Melintas. 28 (1): 61-89. (2012)

[8] Kustedja, Sugiri. Sudikno, Antariksa \& Salura, Purnama.: Kosmologi Media Interpretasi Makna pada Arsitektur Tionghoa Tradisonal. Jurnal Sosioteknologi. 27 (11): 194-231. (2012)

[9] Madeddu, Manuela \& Zhang, Xiaoqing.: Harmonious Spaces: The Influence of Feng Shui on Urban Form and Design. Journal of Urban Design. (2017) 